\title{
Risk and uncertainty in projects management: literature review and conceptual framework
}

João Walter Saunders Pacheco do Vale - Universidade de São Paulo - Departamento de Engenharia de Produção

Marly Monteiro de Carvalho ${ }^{2}$ - Universidade de São Paulo - Departamento de Engenharia de Produção

ABSTRACT This article analyzes the relationship between risk and uncertainty in Project Management. The objective of this paper is to explore the concept of risks and uncertainties in the context of project management and innovation, providing a panorama of the literature. The methodological approach selected is a systematic literature review, merging bibliometrics, network analysis, and content analysis. The results present the most cited authors, keywords networks, research trends and gaps. Both definitions, risks and uncertainties, were analyzed. It could be verified that most publications use the terms as synonyms. This study described the conceptual model that could help research and organizations to understand the main construct and variables related to integrated management systems.

Keywords: Risk. Uncertainty. Project management. Innovation. 


\section{INTRODUCTION}

The use of project risk management practices is still low in organizations (RAZ et al., 2002; ZWIKAEL; GLOBERSON, 2006; ZWIKAEL; SADEH, 2007). Moreover, project management (PM) practitioners and scholars do not clearly distinguish between risk and uncertainty as in other areas of knowledge (PERMINOVA et al., 2008).

Many innovation projects finish far from their initial estimates and are surrounded by uncertainties.

In their study on managing uncertainty in projects, Meyer, Loch and Pich, (2002) noted that risk management is directed to the identification and control of variations and predictable uncertainties. However, for innovation projects or projects embedded in dynamic environments, wherein large uncertainties are concentrated, traditional methods of risk management are not sufficient and there is the need to go beyond and adopt techniques focused on reliability, flexibility, and learning. Goffin and Mitchell (2005) corroborate and suggest that dealing with risk and uncertainty is fundamental to innovation management.

The mainstream of PM literature focuses on risk management, neglecting uncertainty management and soft skills of the project stakeholders in dealing with uncertainties (CRAWFORD et al., 2006; SHARMA; GUPTA, 2012; SÖDERLUND; MAYLOR, 2012).

Despite the prescriptive characteristics of the project management discipline in general (AHLEMANN et al., 2013), and risk management, in particular, the number of academic publications relating to uncertainty has increased during the last few years, and companies have augmented their interest in the application of flexible approach of project management, such as agile project management (DINGSOYR et al., 2012).

Thus, a more detailed analysis of the academic publications relating to risk and uncertainty in PM fields will help to fulfill this research gaps. Thus, the objective of this paper is to explore the concept of risks and uncertainties in the context of project management and innovation, providing a panorama of the literature. The methodological approach applied is the systematic literature review.

The paper is structured in five sections. Section 1 presents the research, its context, and its objectives. Section 2 presents the methodological approach. Section 3 presents the results that were obtained. Section 4 presents a discussion of the findings, and section 5 presents the most important conclusions and contributions of the research. 


\section{RESEARCH METHODS}

The methodological approach used was a systematic review of the literature (SLR) that can be defined as a methodologically rigorous review of research results that aims not just to aggregate all existing evidence but also develop evidence-based guidelines for practitioners (KITCHENHAM et al., 2009).

This study explores the points of intersection between risk and uncertainty literature, applying a SLR with multi-methods combination, merging bibliometrics, network analysis and content analysis. These methods are complementary, as suggested by Carvalho, Fleury and Lopes (2013), and an approach helps to mitigate the other methods weaknesses. For Singhal and Singhal (2012a,b), in Operations Management, there is an increasing interesting in applying multi-methods research.

The bibliometrics is the study of the quantitative aspects of the production, dissemination and use of recorded information (TAGUE-SUTCLIFFE, 1999) and the content analysis is the recognition of the importance of language in human cognition (DURIAU et al., 2007). Thus, while bibliometrics help in the understanding of the publication pattern in main databases, the content analysis goes in dept in analyzing the articles surveyed.

The content analysis allows analytical flexibility. It is conducted at two levels: the manifest content and the latent content. The manifest content of the text can be captured and revealed in a number of text statistics. The latent content and deeper meaning embodied in the text require more interpretation (DURIAU et al., 2007).

The keywords networks were performed using software programs: Sitkis 2.0 (SCHILDT, 2002) and Ucinet and Netdraw (BORGATTI et al., 2002). The most cited keywords.

\subsection{Sample and procedure}

The ISI Web of Knowledge (Web of Science) database was selected for their focus on search journals index in Journal Citation Report (JCR), including from other databases, such as Scopus, Proquest, and Wiley.

Two searches were performed in September 2015. The terms used in the first search were "risk" "innovation" and "Project* management" and in the second search were "uncertaint*", "Project* management" and "innovation". The term innovation was added to the search because uncertainties are inherent to the innovation process. Both searches were investigated in all the databases of the ISI Web of Knowledge, resulting in 82 studies for the first search and 85 for 
the second. The asterisk $\left(^{*}\right)$ inserted into the 2 searches was used as a wildcard character that represented any other character.

Subsequently, the result was filtered by selecting only articles, decreasing the number of studies in the first search to 40 and in the second search to 62 . It was not used other filters such as knowledge area or temporal. These numbers constitute the final search sample. The final samples were published during the period from 1994 (first occurrence for the search of risks) and 1995 (first occurrence for the search of uncertainty) to 2015.

\subsection{Data analysis}

The metadata of the sample of the selected articles was extracted from the ISI databases, and the analyses were performed using two software programs: Sitkis 2.0 (SCHILDT, 2002) and Ucinet for Windows, 6.289 (BORGATTI et al., 2002).

The Sitkis allowed to import the scientific metadata in the Microsoft Access database in an organized manner and to export data from this database into UCINET in a network compatible format. Overall, the Sitkis allowed a quick and easy way to access the bibliometric data, providing cross analysis of the metadata considering article-to-references and keywords (SCHILDT, 2002).

On the other hand, the UCINET, with the extracted file from Sitkis, allowed the development of networks and calculating the bibliometric indices, for instance, Figures 1 and 2 shows the keyword network designed by the UCINET, based on with cross analysis of metadata by Sitkis from keywords, quotes and abstract.

\section{RESULTS}

The search result was divided into five topics: the evolution in the journals of both terms, the main topics related to each term, the most cited papers, the trends in the search for each term and the concept of each term in the literature.

\subsection{Evolution of the publications}

This section presents the list of the core journals for each search on risk and uncertainty strings, considering the number of publications. Table 1 shows the evolution of publications per journal and per year of the first search about risk, including articles published between 1994 (first publication according to search criteria, see 2.1) and 2015. 
Table 1 - Publications per journal and year of the search of risks.

\begin{tabular}{|c|c|c|c|c|c|c|c|c|c|c|c|c|c|c|c|c|c|c|}
\hline JOURNAL & ஃু & Һু & ஃ̊ & $\bar{్}$ & ర్రి & ర్రి & চ্ণ & ర্ণ & ఫ్రి & : & চ্े & 음 & $\overline{\bar{\sigma}}$ & $\stackrel{\sim}{\sim}$ & $\sum_{\sim}^{m}$ & 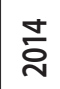 & $\stackrel{n}{\grave{n}}$ & 岕 \\
\hline $\begin{array}{l}\text { International } \\
\text { Journal } \\
\text { OfProject } \\
\text { Management }\end{array}$ & & & & & & & & & & & 3 & & & & & 1 & 2 & 6 \\
\hline $\begin{array}{l}\text { European } \\
\text { Journal Of } \\
\text { Operational } \\
\text { Research }\end{array}$ & 1 & & & & & & & & & 1 & & & & & & & 1 & 3 \\
\hline $\begin{array}{c}\text { leee Transactions } \\
\text { On Engineering } \\
\text { Management }\end{array}$ & & & & & & & 1 & 1 & 1 & & & & & & & & & 3 \\
\hline $\begin{array}{c}\text { Project } \\
\text { Management } \\
\text { Journal }\end{array}$ & & & & & & & & & & & 2 & & & & & & & 2 \\
\hline $\begin{array}{l}\text { Research- } \\
\text { Technology } \\
\text { Management }\end{array}$ & & & & & 1 & & & & 1 & & & & & & & & & 2 \\
\hline $\begin{array}{l}\text { Computers } \\
\text { \&Industrial } \\
\text { Engineering }\end{array}$ & & & & & & & & & & & 1 & & & & & & & 1 \\
\hline $\begin{array}{l}\text { Decision } \\
\text { Sciences }\end{array}$ & & & & & & & & 1 & & & & & & & & & & 1 \\
\hline $\begin{array}{l}\text { Gestão \& } \\
\text { Produçẫo }\end{array}$ & & & & & & & & & & & & & & & & & 1 & 1 \\
\hline $\begin{array}{l}\text { Harvard Business } \\
\text { Review }\end{array}$ & & & & 1 & & & & & & & & & & & & & & 1 \\
\hline $\begin{array}{l}\text { International } \\
\text { Journal Of } \\
\text { Information } \\
\text { Technology \& } \\
\text { Decision Making }\end{array}$ & & & & & & & & & & & & & & & 1 & & & 1 \\
\hline $\begin{array}{l}\text { International } \\
\text { Journal Of } \\
\text { Production } \\
\text { Research }\end{array}$ & & & & & & & & 1 & & & & & & & & & & 1 \\
\hline
\end{tabular}




\begin{tabular}{|c|c|c|c|c|c|c|c|c|c|c|c|c|c|c|c|c|c|c|}
\hline JOURNAL & ఫั & 응 & ஃ̊ & ర্ণ & ઠ్రి & ̊̊. & ఫ્ટે & ๕ั & ठ্ণิ & ஜें & ठे & 음 & $\overline{\grave{D}}$ & స్ & $\stackrel{m}{\grave{N}}$ & ¿্ণ & $\stackrel{n}{\grave{n}}$ & 胥 \\
\hline $\begin{array}{c}\text { International } \\
\text { Journal Of } \\
\text { Research In } \\
\text { Marketing }\end{array}$ & & & & & & & & & & 1 & & & & & & & & 1 \\
\hline $\begin{array}{l}\text { International } \\
\text { Journal Of } \\
\text { Technology } \\
\text { Management }\end{array}$ & & & & & & & & & & & 1 & & & & & & & 1 \\
\hline $\begin{array}{l}\text { Journal Of } \\
\text { Business } \\
\text { Research }\end{array}$ & & & & & & 1 & & & & & & & & & & & & 1 \\
\hline $\begin{array}{l}\text { Journal Of } \\
\text { Construction } \\
\text { Engineering And } \\
\text { Management- } \\
\text { Asce }\end{array}$ & & & & & & & & & & & & 1 & & & & & & 1 \\
\hline $\begin{array}{c}\text { Journal Of } \\
\text { Engineering } \\
\text { And Technology } \\
\text { Management }\end{array}$ & & & 1 & & & & & & & & & & & & & & & 1 \\
\hline $\begin{array}{l}\text { Journal Of } \\
\text { Information } \\
\text { Science }\end{array}$ & & & & & & 1 & & & & & & & & & & & & 1 \\
\hline $\begin{array}{l}\text { Journal Of } \\
\text { Information } \\
\text { Technology }\end{array}$ & & & & & & & & & 1 & & & & & & & & & 1 \\
\hline $\begin{array}{c}\text { Journal Of } \\
\text { Operations } \\
\text { Management }\end{array}$ & & & & & & & & & & & & & & 1 & & & & 1 \\
\hline $\begin{array}{l}\text { Journal Of } \\
\text { Product } \\
\text { Innovation } \\
\text { Management }\end{array}$ & & & & & & & & & & & & 1 & & & & & & 1 \\
\hline $\begin{array}{l}\text { Korean } \\
\text { Management } \\
\text { Consulting } \\
\text { Review. }\end{array}$ & & & & & & & & & & & & & & & 1 & & & 1 \\
\hline
\end{tabular}




\begin{tabular}{|c|c|c|c|c|c|c|c|c|c|c|c|c|c|c|c|c|c|c|}
\hline JOURNAL & ఫั & ๙ૂ & ஃ̊ & চ్రి & రి & ळ్̊․ & ఫ্ণ & ঃั & ઠेે & : & ઠे & 을 & $\bar{i}$ & ָั & $\stackrel{m}{\grave{n}}$ & $\stackrel{ \pm}{\stackrel{D}{\circ}}$ & ํㅗㅎ & 胥 \\
\hline $\begin{array}{c}\text { Management } \\
\text { Decision }\end{array}$ & & & & & & & & & 1 & & & & & & & & & 1 \\
\hline $\begin{array}{l}\text { Management } \\
\text { Science }\end{array}$ & & & & 1 & & & & & & & & & & & & & & 1 \\
\hline $\begin{array}{l}\text { Personalized } \\
\text { Medicine }\end{array}$ & & & & & & & & & & & 1 & & & & & & & 1 \\
\hline $\begin{array}{l}\text { Production And } \\
\text { Operations } \\
\text { Management }\end{array}$ & & & & & & & & & & & & & & & & 1 & & 1 \\
\hline $\begin{array}{c}\text { Production } \\
\text { Planning \& } \\
\text { Control }\end{array}$ & & & & & & & & 1 & & & & & & & & & & 1 \\
\hline $\begin{array}{c}\text { Public Relations } \\
\text { Review }\end{array}$ & & & & & & & & & & & & & 1 & & & & & 1 \\
\hline Technovation & & 1 & & & & & & & & & & & & & & & & 1 \\
\hline Therapie & & & & & & & & 1 & & & & & & & & & & 1 \\
\hline TOTAL & 1 & 1 & 1 & 2 & 1 & 2 & 1 & 5 & 4 & 2 & 8 & 2 & 1 & 1 & 2 & 2 & 4 & 40 \\
\hline
\end{tabular}

Source: The authors.

There is no increasing publication pattern in the analyzed period. The core journals that published more articles on the subject were the International Journal of Project Management, IEEE Transactions on Engineering Management, European Journal of Operational Research, Project Management Journal, and Research-Technology Management.

Table 2 shows the evolution of publications per journal and per year from the second search about uncertainty with articles published between 1995 (first publication according to search criteria) and 2015. 
Table 2 - Publications per journal and year of the search of uncertainty.

\begin{tabular}{|c|c|c|c|c|c|c|c|c|c|c|c|c|c|c|c|c|c|c|}
\hline JOURNAL & ณั & $\stackrel{\circ}{\circ}$ & চ্ণ & $\overline{\grave{n}}$ & ర్ & ळ̊̀े & ఫ્તે & ષ્ণ & চे & ठౖ̊ & ஓ्̀ & 을 & $\bar{i}$ & $\tilde{\check{n}}$ & $\stackrel{m}{\grave{n}}$ & $\stackrel{\nabla}{\circ}$ & $\frac{n}{2}$ & 홍 \\
\hline $\begin{array}{c}\text { International } \\
\text { Journal Of Project } \\
\text { Management }\end{array}$ & & & & & & & & & & & 3 & & 2 & 1 & & 2 & 1 & 9 \\
\hline $\begin{array}{l}\text { leee Transactions } \\
\text { On Engineering } \\
\text { Management }\end{array}$ & 1 & 1 & 1 & & & & 1 & 1 & 1 & & & & & 1 & 1 & & & 8 \\
\hline $\begin{array}{l}\text { Journal Of Product } \\
\text { Innovation } \\
\text { Management }\end{array}$ & & & & & & 1 & & & & 1 & & 1 & & & 3 & & & 6 \\
\hline $\begin{array}{l}\text { Management } \\
\text { Science }\end{array}$ & & & & 3 & 1 & & 1 & & 1 & & & & & & & & & 6 \\
\hline $\begin{array}{c}\text { Project } \\
\text { Management } \\
\text { Journal }\end{array}$ & & & & & & & & & & 2 & 1 & & 1 & & & & & 4 \\
\hline $\begin{array}{c}\text { Journal Of } \\
\text { Engineering } \\
\text { And Technology } \\
\text { Management }\end{array}$ & 2 & & 1 & & & & & & & & & & & & & & & 3 \\
\hline $\begin{array}{l}\text { International } \\
\text { Journal Of } \\
\text { Operations } \\
\text { \&Production } \\
\text { Management }\end{array}$ & & & & & & & & & & & 2 & & & & & & & 2 \\
\hline $\begin{array}{c}\text { Journal Of } \\
\text { Operations } \\
\text { Management }\end{array}$ & & & & & & & & 1 & 1 & & & & & & & & & 2 \\
\hline $\begin{array}{c}R \& D \\
\text { Management }\end{array}$ & & & & & 1 & & & & & 1 & & & & & & & & 2 \\
\hline $\begin{array}{l}\text { Academy Of } \\
\text { Management } \\
\text { Journal }\end{array}$ & & & & & 1 & & & & & & & & & & & & & 1 \\
\hline $\begin{array}{l}\text { European Journal } \\
\text { OfOperational } \\
\text { Research }\end{array}$ & & & & & & & & & & 1 & & & & & & & & 1 \\
\hline $\begin{array}{l}\text { Innovation- } \\
\text { Management } \\
\text { Policy \& Practice }\end{array}$ & & & & & & & & & & & 1 & & & & & & & 1 \\
\hline
\end{tabular}




\begin{tabular}{|c|c|c|c|c|c|c|c|c|c|c|c|c|c|c|c|c|c|c|}
\hline JOURNAL & Кू & §̊ & ஜ্ণ & চे̀ & ర్రి & ஜ్రి & ఫ্ & ஜ̊ & ఫે & ஜ̊ํ & ઠे & 음 & $\overline{\bar{\sigma}}$ & ัָ & m & $\stackrel{+}{\stackrel{\sim}{*}}$ & $\stackrel{n}{\circ}$ & 胥 \\
\hline $\begin{array}{l}\text { International } \\
\text { Journal Of } \\
\text { Information } \\
\text { Technology \& } \\
\text { Decision Making }\end{array}$ & & & & & & & 1 & & & & & & & & & & & 1 \\
\hline $\begin{array}{l}\text { International } \\
\text { Journal Of } \\
\text { Production } \\
\text { Research }\end{array}$ & & & & & & & & 1 & & & & & & & & & & 1 \\
\hline $\begin{array}{l}\text { Journal Of } \\
\text { Construction } \\
\text { Engineering And } \\
\text { Management- } \\
\text { Asce }\end{array}$ & & & & & & & & & & & & 1 & & & & & & 1 \\
\hline $\begin{array}{l}\text { Journal Of } \\
\text { Management \& } \\
\text { Organization }\end{array}$ & & & & & & & & & & & & & 1 & & & & & 1 \\
\hline $\begin{array}{l}\text { Journal Of } \\
\text { Technology } \\
\text { Transfer }\end{array}$ & & & & & & & & & & & & & & 1 & & & & 1 \\
\hline $\begin{array}{l}\text { Journal Of The } \\
\text { Association For } \\
\text { Information } \\
\text { Systems }\end{array}$ & & & & & & & & & & & & & & & 1 & & & 1 \\
\hline $\begin{array}{c}\text { Korean } \\
\text { Management } \\
\text { Consulting Review }\end{array}$ & & & & & & & & & & & & & & & 1 & & & 1 \\
\hline $\begin{array}{c}\text { M\&Som- } \\
\text { Manufacturing \& } \\
\text { Service Operations } \\
\text { Management }\end{array}$ & & & & & & & & & 1 & & & & & & & & & 1 \\
\hline $\begin{array}{l}\text { Management } \\
\text { Decision }\end{array}$ & & & & & & & & & 1 & & & & & & & & & 1 \\
\hline Mis Quarterly & & & & & & & & 1 & & & & & & & & & & 1 \\
\hline $\begin{array}{l}\text { Mit Sloan } \\
\text { Management } \\
\text { Review }\end{array}$ & & & & & & & & & & & & & & & & & 1 & 1 \\
\hline $\begin{array}{l}\text { Organization } \\
\text { Studies }\end{array}$ & & & & & 1 & & & & & & & & & & & & & 1 \\
\hline Research Policy & & & 1 & & & & & & & & & & & & & & & 1 \\
\hline
\end{tabular}




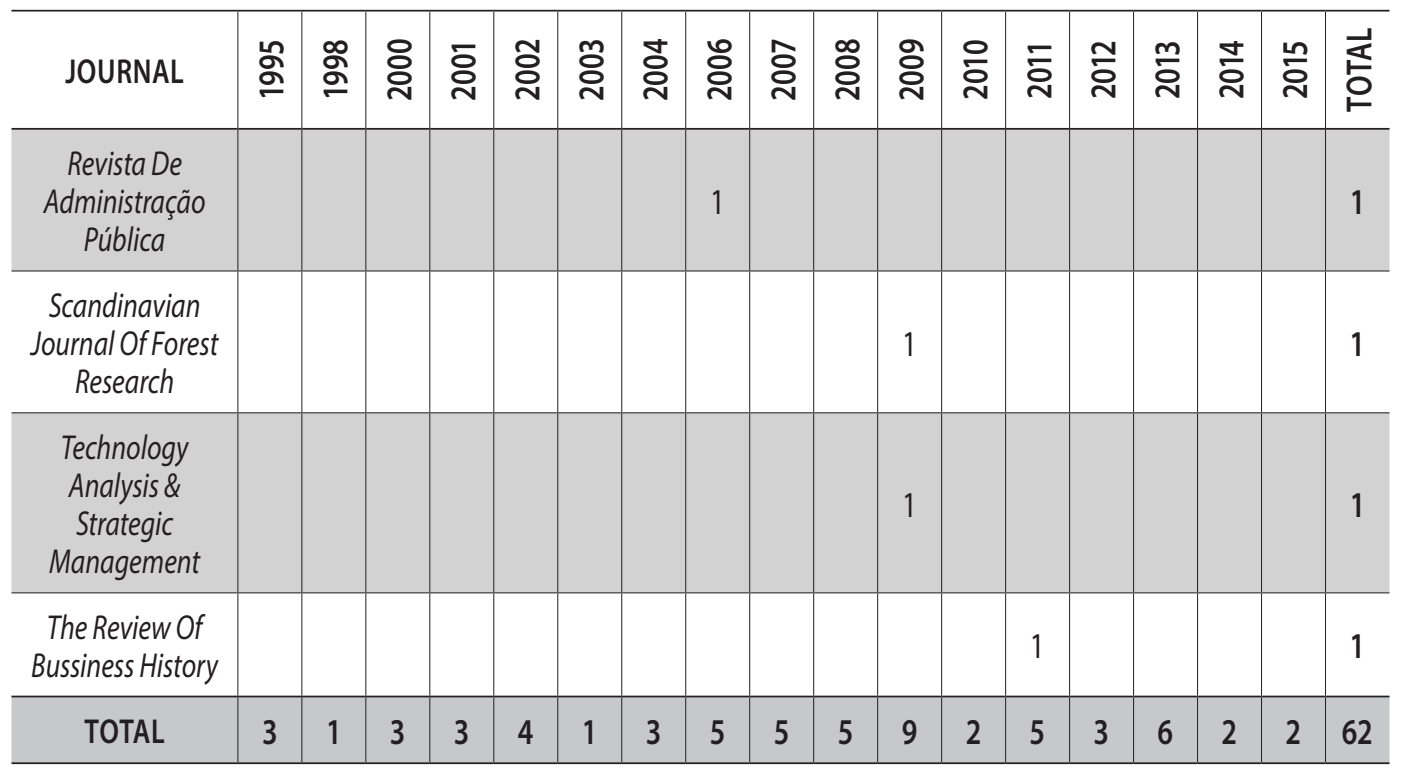

Source: The authors.

Similarly, there is no increasing publication pattern in the analyzed period. The year with the highest number of published articles was 2009 (with 9 articles published), the same year with the highest number of articles on risks (with 8 articles published).

The core journals that published more on the uncertainty subject were IEEE Transactions on Engineering Management, International Journal of Project Management, Management Science and Journal Of Product Innovation Management.

The study of uncertainties presented a greater number of publications but the study was more related to innovation and product development literature, whereas the risk related articles are more aligned with PM literature.

\subsection{Keywords network: main topics and their relation}

Figure 1 shows the keywords network related with the risk surveyed articles. To create this network, a filter of a minimum of three citations of each keyword was used. In the organization of keywords, it was possible to identify four clusters of keywords. At the top is the cluster related to organizational strategy and tactics. At the bottom left is the cluster that attempts to relate risk with uncertainty and complexity, which is a core issue. At the center are the cluster related to competitive advantages, i.e., how risk management relates to success and performance. Finally, on the right side are the cluster related to the type of project analyzed, which are related to product development and radical innovation. 
Figure 1 - Keywords network - risk sample.

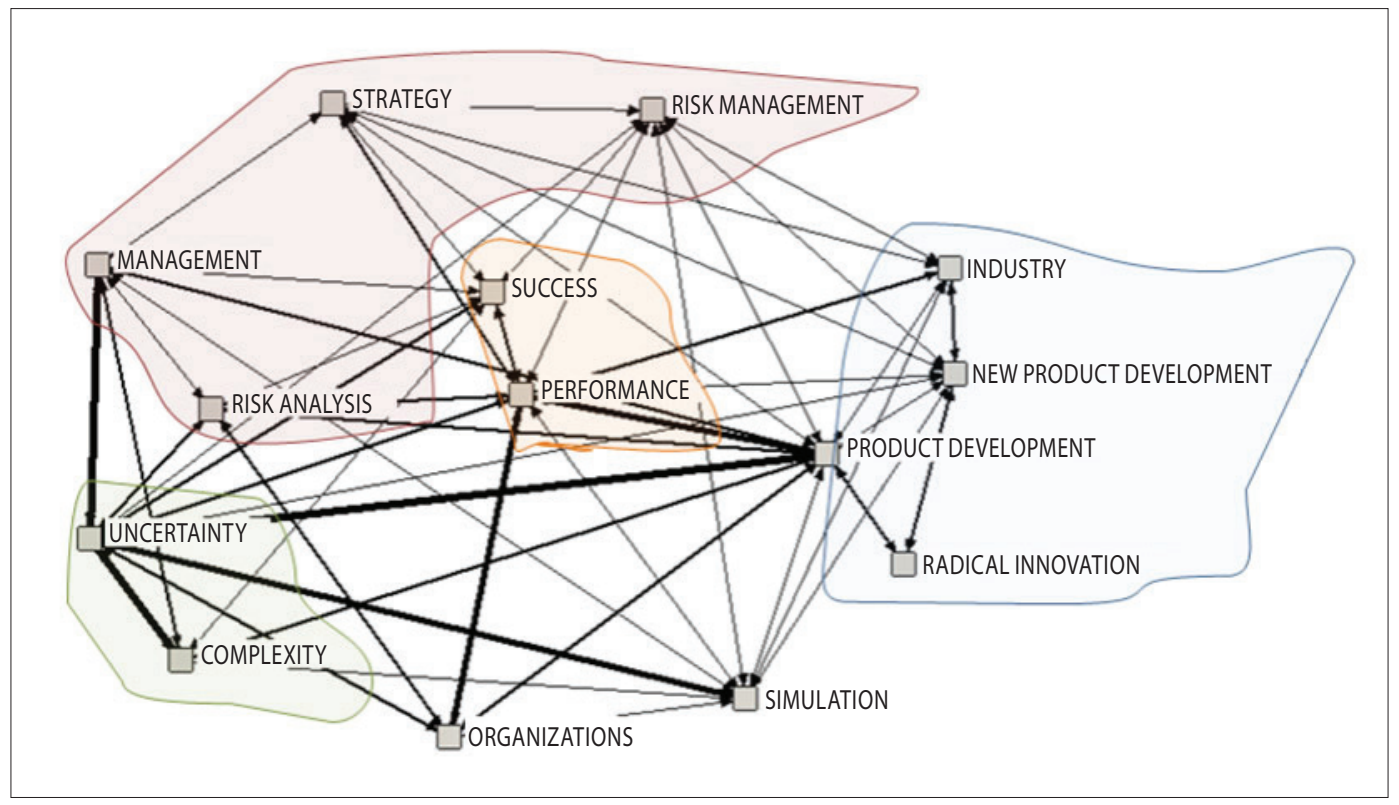

Note: This network was created with Ucinet and Netdraw software using data that was imported using Sitkis software. The strength of ties corresponds to the relationship intensities.

Source: The authors.

Figure 2 shows the keywords network related with the uncertainty surveyed articles. In this network, it was possible to identify five clusters. At the top is the cluster related to strategy and management. At the left side is the cluster related to the type of project analyzed that are product development and product innovation. Similarly to Figure 1, at the center are cluster related to competitive advantages, discussing the impact on success and performance. In the right side, in the lower corner are the keywords most related to the concept of uncertainty in a sense of its cause (ambiguity and complexity) and consequence (failure); and on the right side in the top corner, is the cluster related to environment and organizational context. On the bottom of Figure 2 is the cluster related to the soft side of PM literature such as flexibility, knowledge management and communication. 
Figure 2 - Keywords Network - uncertainty sample.

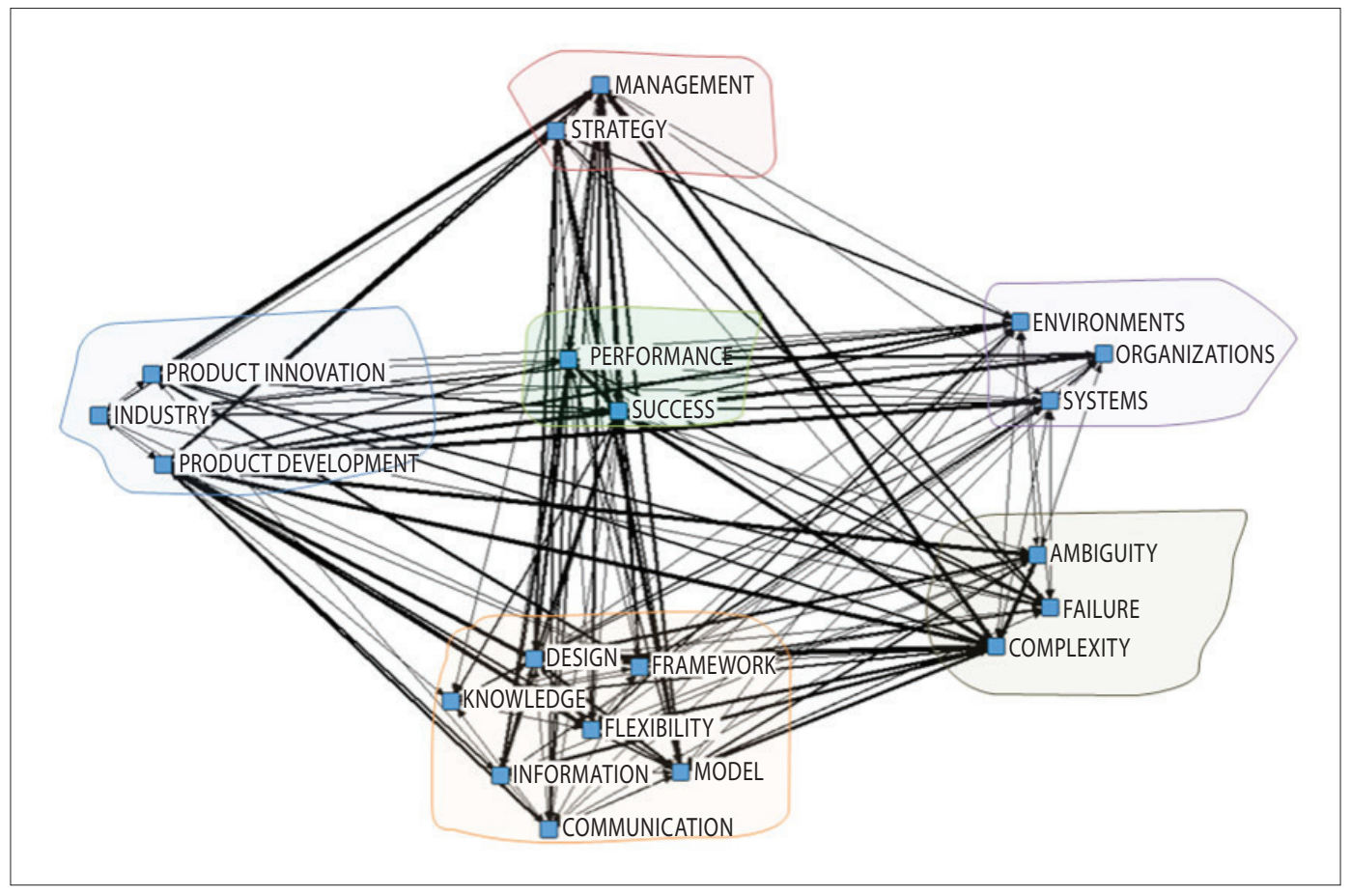

Note: This network was created with Ucinet and Netdraw software using data that was imported using Sitkis software. The strength of ties corresponds to the relationship intensities.

Source: The authors.

The two keywords networks show numerous similarities; the words success and performance emerged from the content analysis as a critical issue. In the literature, the complexity, which is often related to technological complexity, is considered one of the main sources of the uncertainties and risks. Other terms that confirmed the premise that innovations are surrounded by uncertainties included radical innovation, new product development, and product innovation.

A distinction between the two networks, uncertainty and risks, was the cluster related to the soft side in the keywords networks of uncertainty sample, particularly the keywords: flexibility, knowledge, information and communication. Another distinction in the networks is the keywords simulation and risk analysis, which are often related to the risk management processes and tools in PM literature. 


\subsection{Most cited articles}

In bibliometrics, the number of citation is used as a proxy for relevance and impact of the article on the academic community. Thus, it was performed an analysis of the most cited articles.

Of the 40 articles of risk sample, the sum of all citations was 654 . To identify the most cited papers, the cutoff was the Pareto criterion of $80 \%$ of citation, which results in 8 articles (see Table 3). The sum of citations of these articles was 486 , corresponding to $74.3 \%$ of the total citations with the average of 24 citations per year and 3 citations per article per year. These articles are shown in Table 3, Figure 3 shows the yearly citation of these top cited articles.

Table 3 - List of papers with 25 or more citations.

\begin{tabular}{clccc}
\hline ID & \multicolumn{1}{c}{ Article } & Authors & Journal & $\begin{array}{c}\text { Number of } \\
\text { Citations }\end{array}$ \\
\hline 1 & $\begin{array}{l}\text { Project management under risk: } \\
\text { Using the real options approach to } \\
\text { evaluate flexibility in R\&D }\end{array}$ & $\begin{array}{c}\text { Huchzermeier and } \\
\text { Loch (2001) }\end{array}$ & $\begin{array}{c}\text { Management } \\
\text { Science }\end{array}$ & 173 \\
\hline 2 & $\begin{array}{l}\text { Innovation at the speed of } \\
\text { information }\end{array}$ & Eppinger (2001) & Harvard Business \\
Review
\end{tabular}

Source: The authors. 
Figure 3 - Yearly citation of the top cited articles - risk sample.

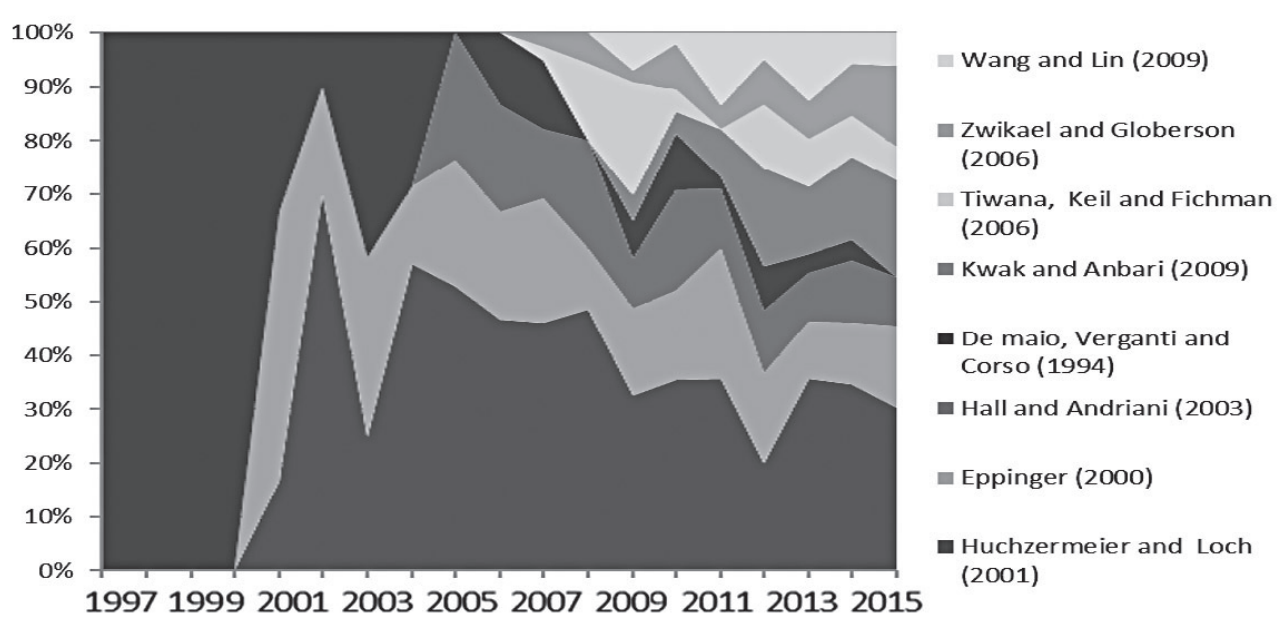

Source: The authors.

The article by Huchzermeier and Loch (2001) was the most cited article in the risk sample. The goal of this article was to present the values of flexible management in Research and Development $(\mathrm{R} \& \mathrm{D})$ projects. The authors used the term uncertainty to indicate stochastic variability. Five types of uncertainties in the R\&D environment and how they influence management flexibility were presented in the article: variability in market payments, budgets, performance, market requirements and deadlines.

Regarding the information flow in the new product development (NPD) process, Eppinger (2001) provided a tool that can simplify the process of iteration. According to this author, the focus of the NPD process should be more on information flow than on the delegation of activities. In this article, the term risk correlated with technological complexity and learning.

With respect to of, Hall and Andriani (2003) discuss the presented knowledge management in the context of innovative projects, including the knowledge acquire needs. Furthermore, the authors correlated risk with the term vulnerability. 
De Maio et. al. (1994) focused on the portfolio level and in the need to manage the interdependence between NPD projects. This article presents an organizational dynamics framework. The authors used the term risk and uncertainty as synonymous. The evolution patterns of this article (see Figure 3 ) exhibited the lose-lose pattern, which was expected because as the first article published in this sample, at the beginning it represents all the citation and lose relative importance as new publications appear.

Tiwana et. al. (2006) noted that managers recognize the value of real options in the decision-making process, on escalation situations in software projects. The real options would be the process of delaying the projects decisions to the latest possible moment to make the decisions with a greater assertiveness and a smaller number of uncertainties. The authors noted the need to have the flexibility to address the uncertainties in the software projects and designated uncertainty as a cause for risk.

For Kwak and Anbari (2009), there is an increasing importance of the risk and uncertainties management by professionals and scholars; however, the concept of risks or uncertainties was not defined in this article.

Wang and Lin (2009) addressed the risks evaluation of the overlapping activities in NPD process. The authors presented a model to analyze the impact of overlapping activities and used the term risk as being an event with an associated probability.

Zwikael and Globerson (2006) described the Critical Success Factors that distinguish the projects that achieved success from those that did not. The author relied on the definition of Meyer et al. (2002), where the uncertainties were classified into 4 types: variation, foreseen uncertainty, unforeseen uncertainty, and chaos.

Regarding the search on uncertainties, from the total of 62 articles, the sum of all citations was 2051. To identify the most cited articles, the cutoff was at least 60 citations per article, and 11 articles were highlighted based on this criterion. The sum of the citations of these articles was 1389, with the average of 69 citations per year. The top articles of uncertainty sample are shown in Table 4 . Figure 4 shows the yearly citation of these top cited articles. 
Table 4 - List of papers with more than 60 citations.

\begin{tabular}{|c|c|c|c|c|}
\hline ID & Article & Authors & Journal & $\begin{array}{l}\text { Number of } \\
\text { Citations }\end{array}$ \\
\hline 1 & $\begin{array}{l}\text { Integrating operations and marketing } \\
\text { perspectives of product innovation: } \\
\text { The influence of organizational } \\
\text { process factors and capabilities on } \\
\text { development performance }\end{array}$ & $\begin{array}{l}\text { Tatikonda and } \\
\text { Montoya-Weiss } \\
\text { (2001) }\end{array}$ & $\begin{array}{l}\text { Management } \\
\text { Science }\end{array}$ & 203 \\
\hline 2 & $\begin{array}{l}\text { One size does not fit all projects: } \\
\text { Exploring classical contingency } \\
\text { domains }\end{array}$ & $\begin{array}{l}\text { Shenhar } \\
\text { (2001) }\end{array}$ & $\begin{array}{l}\text { Management } \\
\text { Science }\end{array}$ & 184 \\
\hline 3 & $\begin{array}{l}\text { Project management under risk: Using } \\
\text { the real options approach to evaluate } \\
\text { flexibility in } R \& D\end{array}$ & $\begin{array}{l}\text { Huchzermeier and } \\
\text { Loch (2001) }\end{array}$ & $\begin{array}{l}\text { Management } \\
\text { Science }\end{array}$ & 173 \\
\hline 4 & $\begin{array}{l}\text { On uncertainty, ambiguity, and } \\
\text { complexity in project management }\end{array}$ & $\begin{array}{l}\text { Pich, Loch and De } \\
\text { Meyer (2002) }\end{array}$ & $\begin{array}{l}\text { Management } \\
\text { Science }\end{array}$ & 164 \\
\hline 5 & $\begin{array}{l}\text { Technology novelty, project } \\
\text { complexity, and product development } \\
\text { project execution success: A deeper } \\
\text { look at task uncertainty in product } \\
\text { innovation }\end{array}$ & $\begin{array}{l}\text { Tatikonda and } \\
\text { Rosenthal (2000) }\end{array}$ & $\begin{array}{l}\text { IEEE Transactions } \\
\text { On Engineering } \\
\text { Management }\end{array}$ & 137 \\
\hline 6 & $\begin{array}{l}\text { Assessing A Multidimensional } \\
\text { Measure Of Radical Technological } \\
\text { Innovation }\end{array}$ & $\begin{array}{l}\text { Green, Gavin and } \\
\text { Aiman-smith (1995) }\end{array}$ & $\begin{array}{l}\text { IEEE Transactions } \\
\text { On Engineering } \\
\text { Management }\end{array}$ & 129 \\
\hline 7 & $\begin{array}{l}\text { Product development tensions: } \\
\text { Exploring contrasting styles of project } \\
\text { management }\end{array}$ & Lewis et al. (2002) & $\begin{array}{l}\text { Academy } \\
\text { Of Management } \\
\text { Journal }\end{array}$ & 101 \\
\hline 8 & $\begin{array}{l}\text { Selectionism and learning in projects } \\
\text { with complexity and unforeseeable } \\
\text { uncertainty }\end{array}$ & $\begin{array}{l}\text { Sommer and } \\
\text { Loch (2004) }\end{array}$ & $\begin{array}{l}\text { Management } \\
\text { Science }\end{array}$ & 88 \\
\hline 9 & $\begin{array}{l}\text { Governmentality matters: Designing } \\
\text { an alliance culture of inter- } \\
\text { organizational collaboration for } \\
\text { managing projects }\end{array}$ & $\begin{array}{l}\text { Clegg et al. } \\
\text { (2002) }\end{array}$ & $\begin{array}{l}\text { Organization } \\
\text { Studies }\end{array}$ & 82 \\
\hline 10 & $\begin{array}{l}\text { Project management characteristics } \\
\text { and new product survival }\end{array}$ & $\begin{array}{l}\text { Thieme, Song and } \\
\text { Shin (2003) }\end{array}$ & $\begin{array}{l}\text { Journal Of Product } \\
\text { Innovation } \\
\text { Management }\end{array}$ & 64 \\
\hline 11 & $\begin{array}{l}\text { Refining the search for project success } \\
\text { factors: a multivariate, typological } \\
\text { approach }\end{array}$ & $\begin{array}{l}\text { Shenhar et al. } \\
\qquad(2002)\end{array}$ & $\begin{array}{c}\text { R\&D } \\
\text { Management }\end{array}$ & 64 \\
\hline
\end{tabular}

Source: The authors. 
Figure 4 - Yearly citation of the top cited articles - uncertainty sample.

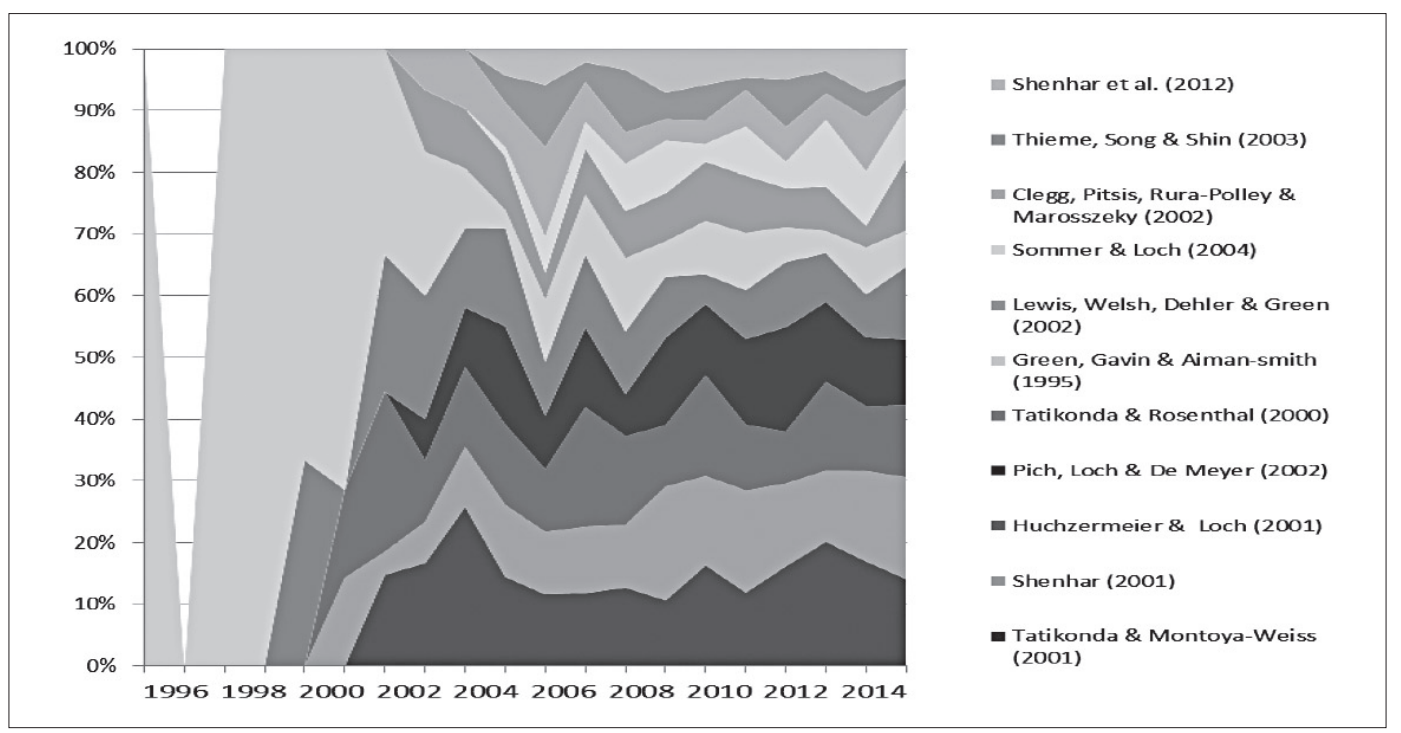

Source: The authors.

Tatikonda and Montoya-Weiss (2001), the most cited article of the uncertainty sample, presented a study on the multidisciplinary in NPD process through the integration of operations with marketing. The term uncertainty was used as an absence of knowledge on the exact means to complete a task or project.

Shenhar has two articles in the top list, the second and 10th article in the rank (see Table 4). Shenhar (2001) indicated that although the PM literature suggests similarities of tools and procedures among the successful projects, the same form of management, including processes and tools, does not fit all projects and contexts. In this paper, projects were classified into four levels of technological uncertainty and three of complexity. The technological uncertainty level was classified as follows: low-tech project, medium-tech projects, high-tech project and super-high-tech project. The complexity dimension is directly related to system scope and is classified as follows: assembly, system, and array. In Shenhar (2002) the key concepts discussed are the some of the article published in 2001, highlighting the contingent approach and the same technological uncertainty classification.

Pich et. al. (2002) is one of the articles with the highest growth in the number of citations (see Figure 4); these authors addressed uncertainties, ambiguity, and complexity in terms of the suitability of the information. In their article, the authors defined three strategies to deal with uncertainties: instructionism, learning,the and selectionism. For these authors, risk was defined as the relationship between the probability of an event and its impact, and uncertainty was defined as a lack of knowledge. 
Tatikonda and Rosenthal (2000) applied the concept of uncertain activity in the context of product development, characterization, and outcome. Their results suggest that the high levels of complexity were not associated with the total failure of the project but with some specific elements of the outcome. The uncertain activity was defined by the authors as the difference between the total knowledge required to perform a task and the existing knowledge in the organization. The concept of technological risks was observed in the article as being synonymous with uncertain activity.

Green et. al. (1995) presented a study on radical technological innovation in which various dimensions were addressed. In the article, the term risk was synonymous with a lack of experience. The term uncertainty was presented as technological uncertainties.

Lewis et al. (2002) found that a mix of management styles increased the performance of the teams. In the context of the article, uncertainty was described as a lack of knowledge.

Clegg et. al. (2002) presented the concept of governmentality applied to Project Management. According to the authors, governmentality would be a liberal form of governance. One of the points addressed by the authors was that governmentality can support quality management in projects, the concept of alliance, knowledge exchange and low-cost transactions. In the article, there was no distinction between the terms risk and uncertainty.

Sommer and Loch (2004) presented selectionism and learning strategies in the context of projects uncertainties. These authors defined unforeseeable uncertainty as that it is not possible to plan contingencies or estimate probabilities.

Thieme et al. (2003) presented a conceptual model to support the NPD. The authors did not distinguish between the terms risk and uncertainty; however, they used the term uncertainty in the context of environment and market. Table 5 summarizes the concepts of risk and uncertainty used by the most cited articles from both searches. 
Table 5 - List with the concepts used by the most cited authors in the first and second search.

\begin{tabular}{|c|c|c|c|}
\hline Author & Article & $\mathrm{R} / \mathrm{U}$ & Concept \\
\hline $\begin{array}{l}\text { Huchzermeier } \\
\text { and Loch } \\
\text { (2001) }\end{array}$ & $\begin{array}{l}\text { Project management under } \\
\text { risk: Using the real options } \\
\text { approach to evaluate flexibility } \\
\text { in } R \& D\end{array}$ & $U$ & Used the term as stochastic variability \\
\hline $\begin{array}{l}\text { Eppinger } \\
(2000)\end{array}$ & $\begin{array}{l}\text { Innovation at the speed of } \\
\text { information }\end{array}$ & $\mathrm{R}$ & $\begin{array}{l}\text { Used the term risk as technological and } \\
\text { learning complexity }\end{array}$ \\
\hline $\begin{array}{l}\text { Hall and Andriani } \\
\qquad(2003)\end{array}$ & $\begin{array}{l}\text { Managing knowledge } \\
\text { associated with innovation }\end{array}$ & $\mathrm{R}$ & Used the term risk as vulnerability \\
\hline $\begin{array}{l}\text { De maio et. al. } \\
\text { (1994) }\end{array}$ & $\begin{array}{l}\text { A Multi-Project Management } \\
\text { Framework For New Product } \\
\text { Development }\end{array}$ & $R / U$ & $\begin{array}{l}\text { Used the term risk as synonymous with } \\
\text { uncertainty }\end{array}$ \\
\hline $\begin{array}{l}\text { Tiwana et. al } \\
\text { (2006) }\end{array}$ & $\begin{array}{l}\text { Information systems project } \\
\text { continuation in escalation } \\
\text { situations: A real options model }\end{array}$ & $R / U$ & Cited uncertainty as a cause for the risk \\
\hline $\begin{array}{l}\text { Kwak and Anbari } \\
\text { (2009) }\end{array}$ & $\begin{array}{l}\text { Analyzing project management } \\
\text { research: Perspectives from top } \\
\text { management journals }\end{array}$ & - & $\begin{array}{l}\text { There was no reference to risks or } \\
\text { uncertainties }\end{array}$ \\
\hline $\begin{array}{l}\text { Wang and Lin } \\
\qquad(2009)\end{array}$ & $\begin{array}{l}\text { An overlapping process model } \\
\text { to assess schedule risk for new } \\
\text { product development }\end{array}$ & $\mathrm{R}$ & $\begin{array}{l}\text { Used the event risk as a doubtful event } \\
\text { with a linked probability }\end{array}$ \\
\hline $\begin{array}{l}\text { Zwikael and } \\
\text { Globerson } \\
\text { (2006) }\end{array}$ & $\begin{array}{l}\text { From Critical Success Factors to } \\
\text { Critical Success Processes }\end{array}$ & $R / U$ & $\begin{array}{l}\text { Designated the term risk as distinct from } \\
\text { uncertainty. Uncertainty was classified } \\
\text { into four types: variation, foreseen } \\
\text { uncertainty, unforeseen uncertainty and } \\
\text { chaos }\end{array}$ \\
\hline $\begin{array}{l}\text { Tatikonda and } \\
\text { Montoya-Weiss } \\
\text { (2001) }\end{array}$ & $\begin{array}{l}\text { Integrating operations and } \\
\text { marketing perspectives of } \\
\text { product innovation: The } \\
\text { influence of organizational } \\
\text { process factors and capabilities } \\
\text { on development performance }\end{array}$ & U & $\begin{array}{l}\text { The term uncertainty was noted in the } \\
\text { article as a lack of knowledge about } \\
\text { the exact means to complete a task or } \\
\text { project }\end{array}$ \\
\hline $\begin{array}{l}\text { Shenhar } \\
\text { (2001) }\end{array}$ & $\begin{array}{l}\text { One size does not fit all } \\
\text { projects: Exploring classical } \\
\text { contingency domains }\end{array}$ & U & $\begin{array}{l}\text { Categorized uncertainties as projects } \\
\text { of low, medium, high, and super-high } \\
\text { technological uncertainty }\end{array}$ \\
\hline
\end{tabular}




\begin{tabular}{|c|c|c|c|}
\hline Author & Article & $R / U$ & Concept \\
\hline $\begin{array}{l}\text { Pich et. al. } \\
\text { (2002) }\end{array}$ & $\begin{array}{l}\text { On uncertainty, ambiguity, } \\
\text { and complexity in project } \\
\text { management }\end{array}$ & $R / U$ & $\begin{array}{l}\text { Risk was defined as the relationship } \\
\text { between the probability of an event } \\
\text { happening and its impact, and } \\
\text { uncertainty was defined as a lack of } \\
\text { knowledge }\end{array}$ \\
\hline $\begin{array}{c}\text { Tatikonda } \\
\text { and Rosenthal } \\
(2000)\end{array}$ & $\begin{array}{l}\text { Technology novelty, project } \\
\text { complexity, and product } \\
\text { development project execution } \\
\text { success: A deeper look at } \\
\text { task uncertainty in product } \\
\text { innovation }\end{array}$ & $R / U$ & $\begin{array}{l}\text { Uncertainty was the difference between } \\
\text { the total knowledge required to perform } \\
\text { a task and the existing knowledge in the } \\
\text { organization; the term risk was used as } \\
\text { uncertain activity }\end{array}$ \\
\hline $\begin{array}{l}\text { Green et. al. } \\
\text { (1995) }\end{array}$ & $\begin{array}{l}\text { Assessing A Multidimensional } \\
\text { Measure Of Radical } \\
\text { Technological Innovation }\end{array}$ & U & $\begin{array}{l}\text { The term was used as technological } \\
\text { doubts }\end{array}$ \\
\hline $\begin{array}{l}\text { Lewis et. al. } \\
\text { (2002) }\end{array}$ & $\begin{array}{l}\text { Product development tensions: } \\
\text { Exploring contrasting styles of } \\
\text { project management }\end{array}$ & U & $\begin{array}{l}\text { The term was used as a lack of } \\
\text { knowledge }\end{array}$ \\
\hline $\begin{array}{l}\text { Clegg et. al. } \\
\text { (2002) }\end{array}$ & $\begin{array}{l}\text { Governmentality matters: } \\
\text { Designing an alliance culture } \\
\text { of inter-organizational } \\
\text { collaboration for managing } \\
\text { projects }\end{array}$ & - & $\begin{array}{l}\text { Risks or uncertainties were not } \\
\text { mentioned }\end{array}$ \\
\hline $\begin{array}{l}\text { Sommer } \\
\text { and Loch } \\
(2004)\end{array}$ & $\begin{array}{l}\text { Selectionism and learning in } \\
\text { projects with complexity and } \\
\text { unforeseeable uncertainty }\end{array}$ & U & $\begin{array}{l}\text { The authors defined unforeseeable } \\
\text { uncertainty as that for which it is not } \\
\text { possible to plan contingencies or } \\
\text { estimate probabilities }\end{array}$ \\
\hline $\begin{array}{l}\text { Thieme, } \\
\text { Song and Shin } \\
\text { (2003) }\end{array}$ & $\begin{array}{l}\text { Project management } \\
\text { characteristics and new } \\
\text { product survival }\end{array}$ & U & $\begin{array}{l}\text { Used the term uncertainty in the context } \\
\text { of an uncertain environment }\end{array}$ \\
\hline
\end{tabular}

Legend: $\mathrm{R}=$ risk; $\mathrm{U}=$ uncertainty.

Source: The Authors.

Table 5 shows that risk and uncertainty were sometimes treated as synonyms; however, some authors presented elements that justified the distinction between these concepts (PERMINOVA et al, 2008; PICH et. al., 2002; DE MEYER et al., 2002; WARD; CHAPMAN, 2003). For these authors, the use of these terms should be distinctive and also the managerial approach applied in each case. Regarding the impacts of risks and uncertainties on the project, there is a consensus concerning the dual perspective, negative or threat viewpoint and the positive or opportunity viewpoint (PERMINOVA et al., 2008). 


\section{DISCUSSION}

Normally, the project risk management is carried out as follows: possible causes are identified, its probability and impact are analyzed by the project team, depending on the risk aversion, a risk response plan is prepared and then the risk is monitored and controlled. The first problem with this approach is that unforeseen uncertainty is ignored. Another problem with this approach is that risk management, in general, analyzes the cause as having only one direct level of effects when in fact it can lead to many other impacts with dynamic interactions among them and can propagate with other levels such as portfolio level.

In general, the effect on the project's objective has been identified and monitored; however, the other possible effects such as the effect on the portfolio, on stakeholders, on the process are ignored because they were not identified or because of the lack of resources in the organization.

In this approach, the resources are using all of their efforts in the risk response plan actions, trying to contain the identified risk.

Complementing this approach, the Hive Structure of Risk and Uncertainty Management is presented as shown in Figure 5. In this approach, the resources are not completely allocated with a focus on a particular risks list but are allocated in a way in which the resources are considered responsible for both risk and uncertainty. Resource in this context is related to human resources.

Figure 5 - Hive Structure of Risk and Uncertainty Management.

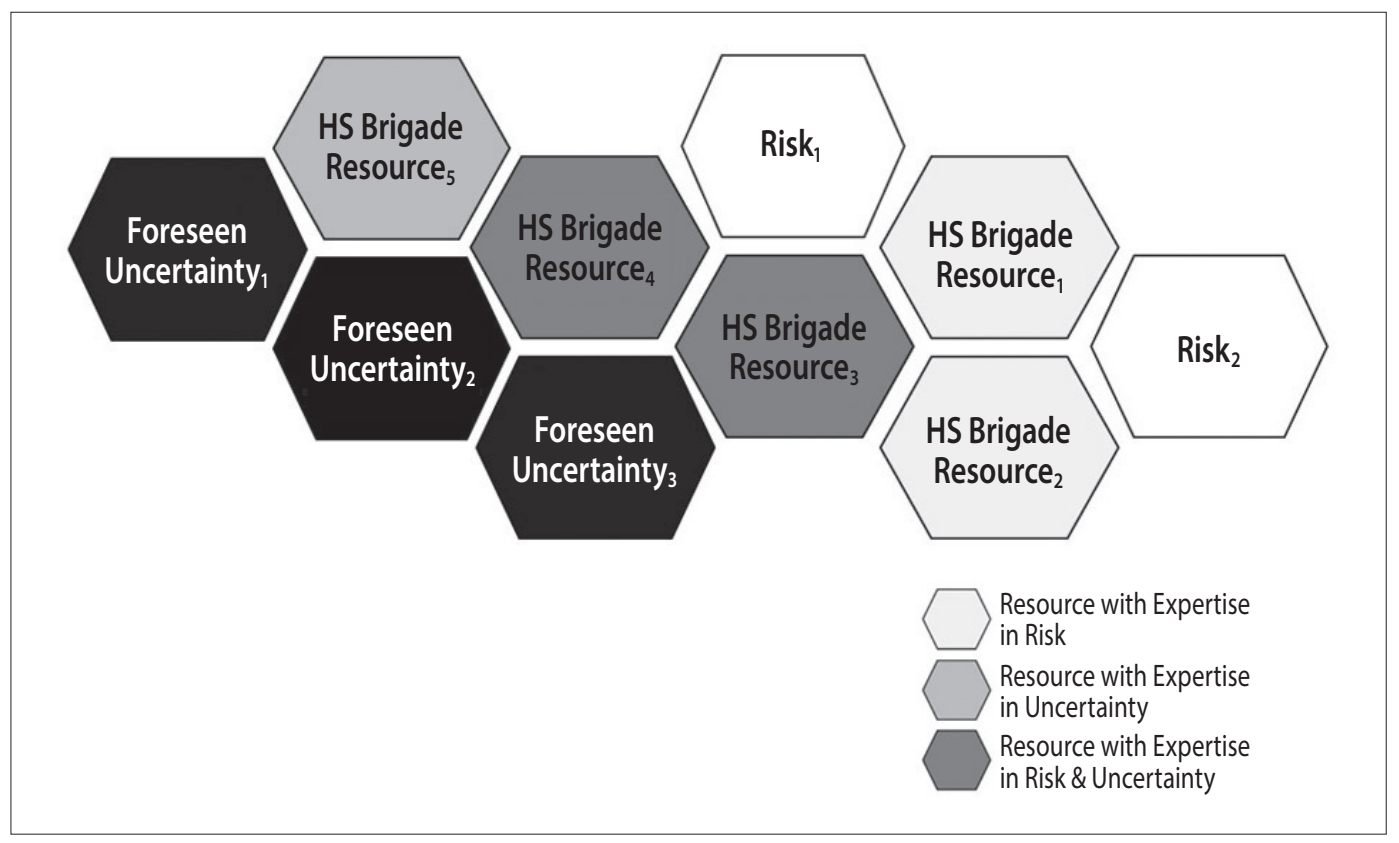

Source: The authors. 
The Hive Structure can be compared to the fire brigade at a company; the brigade is formed by some employees who are selected to be trained. When an uncertainty is manifested, these skilled resources, so-called HS brigade, are able to deliver a fast response. In this structure, employees are trained to know how to proceed with both the project uncertainties and/or project risks.

On the one hand, the traditional approach of the bodies of knowledge (PMI, 2013; IPMA, 2006) focusing on hard skills, structuring processes, tools and techniques to support risk management should be implemented as a qualifier hard skills. However, as suggested by Lechler et al. (2012), even with rigidly planned technical specifications, projects are subject to unpredictable uncertainties (unknown-unknowns), and project management has recently an increasing used the theory of contingency (HANISCH; WALD, 2012).

On the other hand, the soft skills should be enhanced in project teams. The soft skills to deal with uncertainties include flexibility (HUCHZERMEIER; LOCH, 2001), Knowledge Management (HALL; ANDRIANI, 2003), ability to create alliances (Clegg et al., 2002), ability to improvise (LEYBOURNE, 2006) and resilience (THOMAS;MENGEL, 2008). In this scenario, the notion of project ecology (GRABHER, 2004), relying on personal networks among the stakeholders involved, and issues related to the organizational culture, organizational climate, and demographics (CRAWFORD et al., 2006, SHARMA; GUPTA, 2012, SÖDERLUND; MAYLOR, 2012) are critical. Moreover, individual behavior, such as expectations, intuition and judgment, biases, power conflicts, trust, and learning (GLADWELL, 2006, SÖDERLUND; MAYLOR, 2012), is important to deal with uncertainties. The involvement and collaboration across all segments of the project team and its environment are critical issues to effective complex project management (THAMHAIN, 2013).

Figure 6 shows how the strategies for risks and uncertainties management should be performed in an integrated way by the HS brigade. 
Figure 6 - Integrated strategies to manage risk and uncertainties.

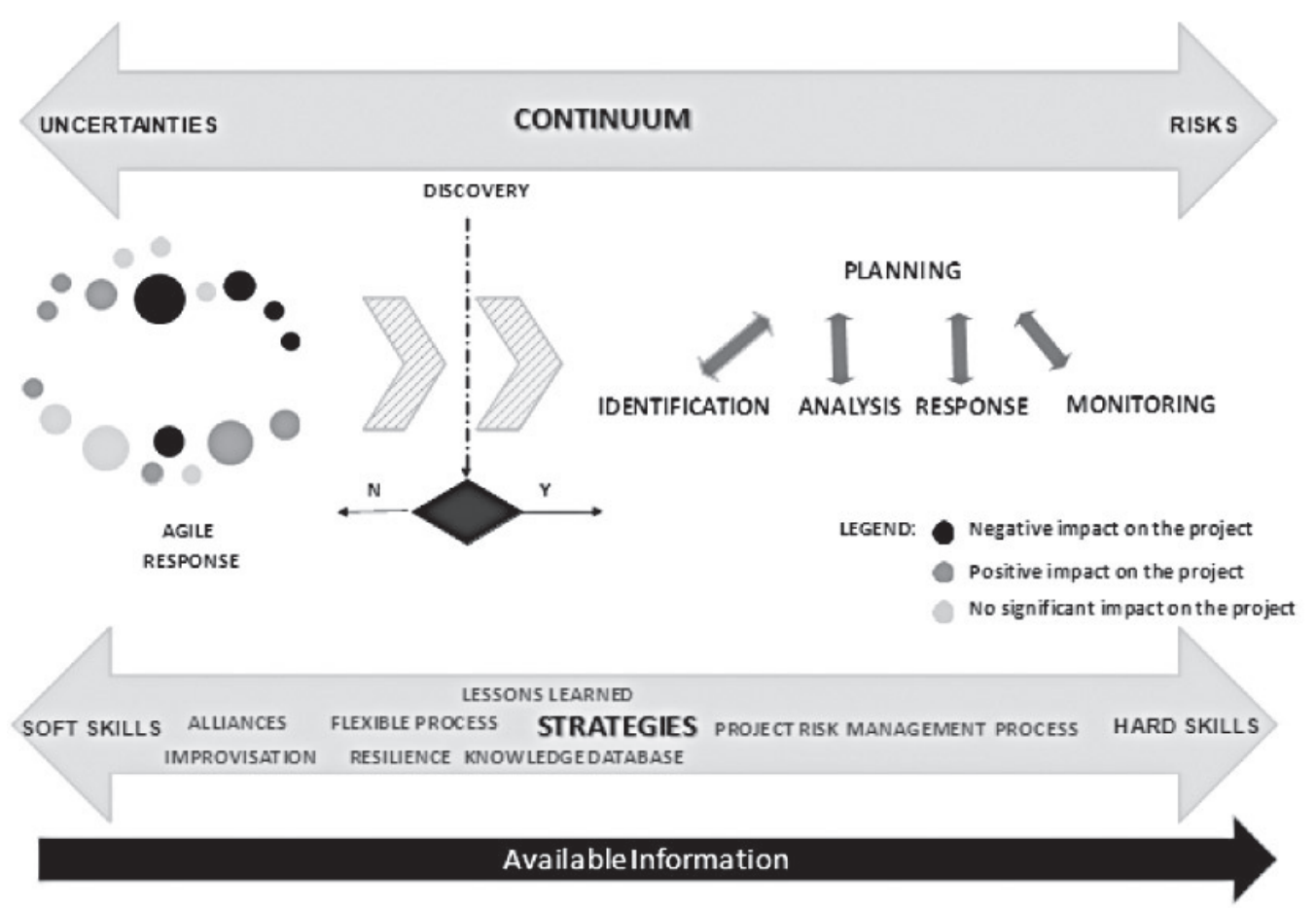

Source: The authors.

This continuum between the unknown to an identified risk demands several distinctive strategies and an organization with the necessary skills. When it is crossed the borderline so-called "discovery" the hard skills could be applied (see Figure 6); however, until this point, the involvement of the key stakeholders and the use of soft skills is the feasible strategy.

\section{CONCLUSIONS}

This study analyzed the concepts of risk and uncertainty in the PM and innovation literature. The surveyed articles were systematically analyzed using a combined approach of literature review methods (bibliometric, network analysis and content analysis). The key journals and the top cited articles are presented and in-depth analyzed.

Although the terms, risks and uncertainties, appear as synonymous in most part of the surveyed articles; these terms have distinct meanings and are used in different contexts. The meaning of risk is closer to a cause and consequence relationship with a linked probability and available information, whereas the 
meaning of uncertainty stands out in the context of a lack of knowledge, when it faces somehow the unknown.

The keywords networks show different pattern concerning to the soft skills that emerge just in the uncertainty sample and is neglected in the risk sample

The Hive Structure identifies the strategy that better fits with different points of the continuum between the unknown to an identified risk. It also reinforces the synergies between the soft and hard skills in PM literature.

This study has practical implications since organizations are investing in the risk management while the strategies should be aligned with the point in the continuum between uncertainty and risk. Thus, the HS can help to understand both - the soft and the hard sides.

This study has limitations relates to the decision to rely on ISI Web of Science for the generation of the initial sample. Despite ISI Web of Science is an important database, and the search process could reach other index journals for other databases, it is reasonable to assume that some relevant papers may not have been included in the sample. Another limitation is the focus on the most cited article as a proxy of relevance, which brings a bias to the oldest articles that had more time to be cited.

Finally, this paper concludes by highlighting directions for future research agenda. The distinction of the uncertainty and risk had been delineated in several studies and taxonomies as discussed in the previous sections, but there is a lack in proposing strategies that fit these distinctive taxonomies. The HS is a conceptual framework that needs field research. In the PM literature, it is important to move on from the hard skill and prescriptive approach to the soft skills and deductive approach, but as complementary approaches in the uncertainty and risk continuum.

\section{ACKNOWLEDGEMENTS}

The authors gratefully acknowledge the financial support of the Brazilian research funding agencies $\mathrm{CNPq}$ (National Council for Scientific and Technological Development) and FAPESP (São Paulo Research Foundation).

\section{REFERENCES}

AHLEMANN, F.; EL ARBI, F.; KAISER, M. G.; HECK, A. A process framework for theoretically grounded prescriptive research in the project management field. International Journal of Project Management, v. 31, n. 1, p. 43-56, 2013. 
BARDIN, L. Análise de conteúdo. Lisboa: Edições 70, 1979.

BORGATTI, S. P.; EVERETT, M. G.; FREEMAN, L. C. Ucinet for Windows: Software for Social Network Analysis. Harvard, MA: Analytic Technologies. 2002.

CARVALHO, M. M.; FLEURY, A., LOPES, A. P. An overview of the literature on technology roadmapping (TRM): Contributions and trends. Technological Forecasting \& Social Change, v. 80, p. 1418-1437. 2013.

CLEGG, S. R.; PITSIS, T. S.; RURA-POLLEY, T.; MAROSSZEKY, M. Governmentality matters: designing an alliance culture of inter-organizational collaboration for managing projects. Organization Studies, v. 23, n. 3, p. 317-337, 2002.

CRAWFORD, L.; MORRIS, P.; THOMAS, J.; WINTER, M. Practitioner development: from trained technicians to reflective practitioners. International Journal of Project Management, v. 24, n. 8, p. 722-733. 2006.

DE MAIO, A.; VERGANTI, R.; CORSO, M. A multi-project management framework for new product development. European Journal of Operational Research, v. 78, n. 2, p. 178-191. 1994.

DE MEYER, A.; LOCH, C. H.; PICH, M. T. From variation to chaos. MIT Sloan Management Review, v. 43, n. 2, p. 60-7. 2002.

DINGSOYR, T.; NERUR, S.; BALIJEPALLY, V.; MOE, N. A decade of agile methodologies: Towards explaining agile software development. Journal of Systems and Software, v. 85, n. 6, p. 1213-1221. 2012.

DURIAU, V.J; REGER, R.K.; PFARRER, M.D. A Content Analysis of the Content Analysis Literature in Organization Studies Research Themes, Data Sources, and Methodological Refinements. Organizational Research Methods, v. 10, n. 1, p. 5-34, 2007.

EPPINGER, S. D. Innovation at the Speed of Information. Harvard Business Review, v. 79, n. 1, p. 149-158. 2001.

GLADWELL, M. Blink: The Power of Thinking without Thinking, Penguin, London, UK. 2006.

GOFFIN, K.; MITCHELL, R. Innovation management. Palgrave Macmillan. 2005. 
GRABHER, G. Learning in projects, remembering in networks? Communality, sociality and connectivity in project ecologies. European Urban and Regional Studies, v. 11, n. 2, p. 103-123. 2004.

GREEN, S. G.; GAVIN, M. B.; AIMAN-SMITH, L. Assessing a multidimensional measure of radical technological innovation. Engineering Management, IEEE Transactions on, v. 42, n. 3, p. 203-214. 1995.

HALL, R.; ANDRIANI, P. Managing knowledge associated with innovation. Journal of Business Research, v. 56, n. 2, p. 145-152, 2003.

HANISCH, B.; WALD, A. A Bibliometric View on the Use of Contingency Theory in Project Management Research. Project Management Journal, v. 43, n. 3, p. 4-23, 2012.

HUCHZERMEIER, A.; LOCH, C. H. Project Management Under Risk: Using the Real Options Approach to Evaluate Flexibility. R D. Management Science, v. 47, n. 1, p. 85-101, 2001.

IPMA - International Project Management Association. Competency Baseline. Nijkerk: IPMA. 2006.

THIEME, J. R.; SONG, M. S X.; SHIN, G. C. Project management characteristics and new product survival. Journal of Product Innovation Management, v. 20, n.2, p. 104-119, 2003.

KITCHENHAM, B.; BRERETON. O.P.; BUDGEN. D.; TURNER, M.; BAILEY, J.; LINKMAN, S. Systematic literature reviews in software engineering - A systematic literature review. Information and Software Technology, v. 51, n. 9, p. 7-15, 2009.

KWAK, Y. H.; ANBARI, F. T. Analyzing project management research: Perspectives from top management journals. International Journal of Project Management, v. 27, n. 5, p. 435-446, 2009.

LECHLER, T. G.; EDINGTON, B. H.; GAO, T. Challenging Classic Project Management: Turning Project Uncertainties Into Business Opportunities. Project Management Journal, v. 43, n. 6, p. 59-69, 2012.

LEWIS, M. W.; WELSH, M. A.; DEHLER, G. E.; GREEN, S. G. Product development tensions: exploring contrasting styles of project management. Academy of Management Journal, v. 45, n. 3, p. 546-564, 2002. 
LEYBOURNE, S. A. Managing improvisation within change management: Lessons from UK financial services. The Service Industries Journal, v. 26, n. 1, p. 73-95, 2006.

PERMINOVA, O.; GUSTAFSSON, M.; WIKSTRÖM, K. Defining uncertainty in projects-a new perspective. International Journal of Project Management, v. 26, n. 1, p. 73-79, 2008.

PICH, M. T.; LOCH, C. H.; DE MEYER, A. On uncertainty, ambiguity, and complexity in project management. Management Science, v. 48, n.8, p. 1008 1023, 2002.

PMI. A guide to the Project management body of knowledge, 5 Ed. EUA: Project Management Institute, 2013.

RAZ, T.; SHENHAR, A. J.; DVIR, D. Risk management, project success, and technological uncertainty. R\&D Management, v. 32, n. 2, p. 101-109, 2002.

SCHILDT, H. A. SITKIS: Software for Bibliometric Data Management and Analysis. Helsinki: Institute of Strategy and International Business, v. 6, 2002.

SHARMA,A.; GUPTA A. Impact of organizational climate and demographics on project specific risks in context to Indian software industry. International Journal of Project Management, v. 30, n. 2, p. 176-187, 2012.

SHENHAR, A. J.; TISHLER, A.; DVIR, D.; LIPOVETSK, S.; LECHLER, T. Refining the search for project success factors : a multivariate, typological approach. R\&D Management, v. 32, n. 2, p. 111-126, 2002.

SHENHAR, A. J. One size does not fit all projects: exploring classical contingency domains. Management Science, v. 47, n. 3, p. 394-414, 2001.

SINGHAL, K., SINGHAL, J. Imperatives of the science of operations and supply-chain management. Journal of Operations Management, v. 30, n.3, p. 237-244, 2012a.

SINGHAL, K.; SINGHAL, J. Opportunities for developing the science of operations and supplychain management. Journal of Operations Management, v. 30, n. 3, p. 245-252, 2012b.

SÖDERLUND, J.; MAYLOR, H. Project management scholarship: Relevance, impact and five integrative challenges for business and management schools. International Journal of Project Management, v. 30, n. 6, p. 686-696, 2012. 
SOMMER, S. C.; LOCH, C. H. Selectionism and learning in projects with complexity and unforeseeable uncertainty. Management Science, v. 50, n. 10, p. 1334-134, 2004.

TAGUE-SUTCLIFFE, J. An introduction to informetrics. Information Processing \& Management, 28, n. 1, p. 1-3, 1992.

TATIKONDA, M. V;; MONTOYA-WEISS, M. M. Integrating operations and marketing perspectives of product innovation: The influence of organizational process factors and capabilities on development performance. Management Science, v. 47, n. 1, p. 151-172, 2001.

TATIKONDA, M. V.; ROSENTHAL, S. R. Technology novelty, project complexity, and product development project execution success: a deeper look at task uncertainty in product innovation. Engineering Management, IEEE Transactions on, v. 47, n. 1, p. 74-87, 2000.

THAMHAIN, H. Managing Risks in Complex Projects. Project Management Journal, v. 44, n. 2, p. 20-35, 2013.

THOMAS, J.; MENGEL, T. Preparing project managers to deal with complexity-Advanced project management education. International Journal of Project Management, v. 26, n.3, p. 304-315, 2008.

TIWANA, A.; KEIL, M.; FICHMAN, R. G. Information systems project continuation in escalation situations: A real options model. Decision Sciences, v. 37, n. 3, p. 357-391, 2006.

WANG, J.; LIN, Y. I. An overlapping process model to assess schedule risk for new product development. Computers \& Industrial Engineering, v. 57, n. 2, p. 460-474, 2009.

WARD, S.; CHAPMAN, C. Transforming project risk management into project uncertainty management. International Journal of Project Management, v. 21, n. 2, p. 97-105, 2003.

ZWIKAEL, O.; SADEH, A. Planning effort as an effective risk management tool. Journal of Operations Management, v. 25, n. 4, p. 755-767, 2007.

ZWIKAEL, O.; GLOBERSON, S. From critical success factors to critical success processes. International Journal of Production Research, v. 44, n. 17, p. 3433 3449, 2006. 